\title{
The Mechanism of Extraction of Peanut Protein and Oil Bodies by Enzymatic Hydrolysis of the Cell Wall
}

\author{
Chen Liu', Li-hua Hao ${ }^{2}$, Fu-sheng Chen ${ }^{1 *}$, and Ting-wei Zhu ${ }^{1}$ \\ ${ }^{1}$ College of Food Science and Technology, Henan University of Technology, Zhengzhou 450001, CHINA \\ ${ }^{2}$ Henan Institute of Product Quality Supervision and Inspection, Zhengzhou 450001, CHINA
}

\begin{abstract}
Degradation of the peanut cell wall is a critical step in the aqueous enzymatic extraction process to extract proteins and oil bodies. Viscozyme ${ }^{\circledR} \mathrm{L}$, a compound cell wall degrading enzyme, has been applied as an alternative to protease in the process of aqueous enzymatic extraction, but the mechanism of cell wall enzymolysis remains unclear. The present study aims to investigate the changes in cellulose, hemicellulose, and pectin content of the peanut cell wall hydrolyzed by Viscozyme ${ }^{\circledR} L$. The degree to which the main components of the peanut cell wall, such as trans-1, 2-cyclohexanediamine- $N, N, N^{\prime}, N^{\prime}$-acetic acid-soluble pectin (CDTA-soluble pectin), $\mathrm{Na}_{2} \mathrm{CO}_{3}$-soluble pectin, cellulose, and hemicellulose, are degraded is closely related to the extraction of oil bodies and peanut protein at different solid-liquid ratio of powered peanut seed in distilled water, enzyme concentration, enzyme hydrolysis temperature, and enzyme hydrolysis time. The key sites of Viscozyme ${ }^{\circledR} L$ activity on cell wall polysaccharides were explored by comparing the changes in chemical bonds under different extraction conditions using Fourier-transform infrared spectroscopy (FTIR) absorption bands and principal component analysis (PCA). Viscozyme ${ }^{\circledR} \mathrm{L}$ acted on the C-O stretching, $\mathrm{C}-\mathrm{C}$ stretching, and $\mathrm{CH}_{2}$ symmetrical bending of cellulose, the $\mathrm{C}-\mathrm{O}$ stretching and $\mathrm{O}-\mathrm{C}-\mathrm{O}$ asymmetrical bending of hemicellulose, and the $\mathrm{C}-\mathrm{O}$ stretching and $\mathrm{C}-\mathrm{C}$ stretching of pectin.
\end{abstract}

Key words: aqueous enzymatic extraction, Viscozyme ${ }^{\circledR}$ L, principal component analysis, oil body, cell wall

\section{Introduction}

Aqueous enzymatic extraction is a promising method for extraction of oils and proteins from oilseeds, in which water is used as the extraction solvent ${ }^{1)}$. Compared with the traditional oil extraction process, aqueous enzymatic extraction has the advantages of being environmentally friendly, nonuse of organic solvents, low energy consumption, and mild reaction conditions ${ }^{2,3}$. Furthermore, peanut oil requires low degree of refinement and peanut protein can be recycled at the same time ${ }^{4-6)}$. Cell wall degrading enzymes, such as cellulase, hemicellulase, and pectinase, can degrade the main components and destroy the structure of the cell wall without affecting the peanut protein. Bisht et $a l^{7}{ }^{7}$ showed that cellulase, hemicellulase, and pectinase alone or their complex enzymes could effectively increase the oil yield at appropriate concentrations; e.g., the combination of cellulase and pectinase increased the oil yield by $14.22 \%$. Szydłowska-Czerniak et al. ${ }^{8)}$ reported a higher yield of rapeseed oil extracted by pectinase and cellulase compared with the yield obtained by traditional methods, with pectinase having better effect on extracting rapeseed oil than cellulase. The degradation of the peanut cell wall in aqueous enzymatic extraction is a critical step that facilitates the release of peanut proteins and oil bodies. Viscozyme ${ }^{\circledR}$ L, a compound cell wall degradation enzyme, promotes the release of nonhydrolyzed protein and oil bodies by degrading the main components and destroy the structure of the cell wall without affecting the peanut protein ${ }^{9,10)}$, but enzyme active sites of Viscozyme ${ }^{\circledR}$ $\mathrm{L}$ and the mechanism of degradation of the peanut cell wall in aqueous enzymatic extraction remain unclear.

Fourier-transform infrared spectroscopy (FT-IR) has been applied to monitor the extraction of cell wall polysaccharides and to observe the changes in the cell wall during the processing and quality control of fruits and vegetables $^{11,12)}$. The optimal region of FT-IR spectrum used for carbohydrate analysis is $1200-850 \mathrm{~cm}^{-1}$ and $1800-1200 \mathrm{~cm}^{-1}$; the former region is not affected by the spectrum bands of proteins and water molecules ${ }^{13)}$. The region $1200-850 \mathrm{~cm}^{-1}$ mainly reflects the stretching and vibration characteristics of $\mathrm{C}-\mathrm{O}, \mathrm{C}-\mathrm{C}$, and $\mathrm{CH}_{2}$ groups or the ring structure formed by these groups ${ }^{14)}$. To obtain relatively complete cell wall

*Correspondence to: Fu-sheng Chen, College of Food Science and Technology, Henan University of Technology, Zhengzhou 450001, CHINA

E-mail: fushengc@ haut.edu.cn

Accepted August 11, 2020 (received for review May 31, 2020)

Journal of Oleo Science ISSN 1345-8957 print / ISSN 1347-3352 online

http://www.jstage.jst.go.jp/browse/jos/ http://mc.manusriptcentral.com/jjocs 
information, both regions, $1800-1200 \mathrm{~cm}^{-1}$ and $1200-850$ $\mathrm{cm}^{-1}$, were used for FT-IR spectrum analysis in this study. Principal component analysis (PCA) is a common data statistics method used to simplify and analyze highly dimensional data sets by constructing principle components (PCs) that explain the maximum variability of the data. PCA is particularly suitable for analysis of the infrared spectrum characteristics in relation to sample diversity and complexity ${ }^{15)}$. FT-IR spectroscopy combined with PCA is very useful for determining structural and compositional changes in the cell wall ${ }^{12,16)}$, for assessing the degree of amidation and methyl esterification of pectic polysaccharides in plant cell wall extracts ${ }^{17,18)}$, and for evaluating cell wall polysaccharides composition of pectic and hemicellulosic components derived from plant materials ${ }^{19)}$.

In the present study, the changes in cellulose, hemicellulose, and pectin content in the peanut cell wall hydrolyzed by Viscozyme ${ }^{\circledast}$ L were examined under different solid-liquid ratios, enzyme concentrations, enzyme hydrolysis temperatures, and enzyme hydrolysis times. The characteristic FT-IR absorption bands of cellulose, hemicellulose, and pectin in the cell wall of peanut were analyzed by PCA to explore the key sites of Viscozyme ${ }^{\circledast}$ L activity on peanut cell wall during enzymatic hydrolysis. The mechanism of cell wall enzymolysis studied in this paper will provide theoretical basis for further explorations of the mechanism of aqueous enzymatic extraction and help to enhance the extraction of peanut protein and oil bodies.

\section{Materials and Methods}

\subsection{Materials}

Peanut seeds were purchased from the local market (Zhengzhou, China) and stored at $4^{\circ} \mathrm{C}$ until their use. The seeds were composed of (g/100 g dry matter) $46.84 \%$ oil, $24.44 \%$ protein, $4.65 \%$ crude fiber, $4.63 \%$ water, and $2.35 \%$ ash. Viscozyme ${ }^{\circledast}$ L (complex plant hydrolase; 5086 $\mathrm{U} / \mathrm{mL}$; the main ingredients are cellulase, hemicellulose, and arabinose) was purchased from Novozymes (Novo, China). All other reagents used were of analytical grade.

\subsection{Extraction of proteins and oil bodies}

Peanut protein and oil bodies were extracted using the graded extraction method ${ }^{20)}$ and aqueous enzymatic extraction of maize germ ${ }^{21)}$, respectively, with some modifications. The skinless peanut seeds were ground in a highspeed universal grinder (FW-100; Beijing Ever Bright Medical Treatment Inc, Beijing, China). Twenty grams of peanut powder was dispersed in deionized water (the solidto-liquid ratio of 1:7, 1:6, 1:5, 1:4, 1:3, and 1:2 w/v). Viscozyme $^{\circledast} \mathrm{L}(0.25,0.50,0.75,1.00,1.25,1.50,1.75$, and $2.0 \%$, calculated by the weight of total substrate) was added to the mixture and enzymolysis was conducted in a digital water-bathing constant temperature vibrator(THZ-82; Jinhua Huafeng Instrument Inc, Jinhua, China) for different times $(20,40,60,80,100,120$, and $140 \mathrm{~min})$ and at different temperatures $\left(35,40,45,50,55,60,65\right.$, and $\left.70^{\circ} \mathrm{C}\right)$. Thereafter, the enzyme was deactivated by placing the samples in a boiling water bath for $5 \mathrm{~min}$. The cooled solution was centrifuged at $5000 \times g$ for $20 \mathrm{~min}$ (DZ267-32C6; Anting Scientific Instrument Factory, Shanghai, China). The supernatant (oil bodies) was decanted and dried at 50 ${ }^{\circ} \mathrm{C}$ for $10 \mathrm{~h}$ in a vacuum drying oven(DZF-2B; Beijing Ever Bright Medical Treatment Inc, Beijing, China), whereas the precipitation was dried in a freezer dryer (LGJ-25; Beijing Sihuan Scientific Instrument Inc, Beijing, China) for $24 \mathrm{~h}$ and weighed. The amount of protein was measured by an Automatic Kjeldahl Apparatus (K1100; Jinan Haineng Instrument Inc, Shandong, China), and the yields of protein and oil bodies were calculated using the formula 1 and 2 , respectively:

$$
\begin{aligned}
& \text { Yield of peanut protein }= \\
& \frac{\text { protein content of precipitate }}{\text { protein content of peanut }} \times 100(\%) \\
& \text { Yield of oil bodies }= \\
& \frac{\text { dry weight of oil bodies }}{\text { weight of peanut sample }} \times 100(\%)
\end{aligned}
$$

\subsection{Extraction and determination of the main cell wall components}

Sodium dodecyl sulfate solution $(15 \mathrm{~g} / \mathrm{L}$, containing 5 $\mathrm{mmol} / \mathrm{L}$ pyrosulfite) was added to the dried precipitate obtained as described in 2.2 and centrifuged twice at $4000 \times g$ for $15 \mathrm{~min}$. The new precipitate was treated with $90 \%$ dimethyl sulfoxide to remove starch and then cleaned by several cycles of washing with distilled water and centrifugation to obtain cell wall material $(\mathrm{CWM})^{22)}$. The CWM was treated with $50 \mathrm{~mL}$ 2-cyclohexanediamine- $N, N, N^{\prime}, N^{\prime}$-acetic acid (CDTA; $50 \mathrm{mmoL} / \mathrm{L}, \mathrm{pH} 6.5)$ for $6 \mathrm{~h}$ at $25^{\circ} \mathrm{C}$. CDTA-soluble pectin in the supernatant was obtained by filtration through a nylon membrane with $10 \mu \mathrm{m}$ pore diameter. The remaining solid was incubated in $50 \mathrm{~mL} \mathrm{Na} \mathrm{CO}_{3}$ solution ( 50 $\mathrm{mmoL} / \mathrm{L}$, containing $20 \mathrm{mmol} / \mathrm{L} \mathrm{NaBH}{ }_{4}$ ) at $25^{\circ} \mathrm{C}$ for $6 \mathrm{~h} . \mathrm{Na}_{2}$ $\mathrm{CO}_{3}$-soluble pectin in the supernatant was obtained by filtration through a nylon membrane with $10 \mu \mathrm{m}$ pore diameter. Cellulose in the supernatant and hemicellulose in the precipitation were obtained after adding $50 \mathrm{~mL} 4 \mathrm{M}$ potassium hydroxide to the remaining solid and reacting for $12 \mathrm{~h}$ at $25^{\circ} \mathrm{C}^{23)}$. The amount of pectin was determined by the carbazole colorimetric method ${ }^{24)}$, and the amount of hemicellulose and cellulose was determined by the anthrone colorimetric method $^{25,26)}$.

\subsection{Analysis of cell wall components by FT-IR}

The infrared spectra of the peanut cell wall were assembled from 64 scans obtained at a resolution of $4 \mathrm{~cm}^{-1}$ between 4000 and $650 \mathrm{~cm}^{-1}$ using a Fourier-transform 
spectrometer VERTEX 70 (Bruker, Ettlingen, Germany) ${ }^{27}$.

\subsection{Statistical analysis}

All the experiments were carried out at least three times using duplicate samples, and the results are presented as mean \pm standard deviation. The data were statistically analyzed using Design Expert 8.05b, Origin 8.5, and SPSS 19.0. A value of $p<0.05$ was considered statistically significant.

\section{Results and Discussion}

\subsection{Effects of enzyme hydrolysis parameters on the yield of protein and oil bodies}

The extraction rate of protein reached maximum value $(88.69 \%)$ at $1: 2$ solid-liquid ratio, but decreased and tended to level out as the ratio increased (Fig. 1a). Such a trend could be attributed to gradual dissolution of watersoluble whey protein and salt-soluble arachin and conarachin with the increase in the solid-to-liquid ratio until reaching the threshold at which arachin and conarachin were non-degradable due to their stable spatial structure ${ }^{28,29)}$. The yield of oil bodies increased and then decreased; it reached the maximum $(42.37 \%)$ at the solid-liquid ratio of $1: 4$. The increase in the aqueous solution promoted the decomposition of peanut cell wall structure, but further increase in the solid-liquid ratio reduced the enzyme activity, resulting in decreased yield of oil bodies. The yield of both protein and oil bodies initially increased and then decreased, with both reaching maximum levels $(68.45 \%$ and $39.28 \%$, respectively) at the enzyme concentration of $1.25 \%$ (Fig. 1b). Increasing the enzyme concentration to a certain level increased the degree of cell wall damage and allowed that protein and oil bodies were released in the cell at a relatively stable rate. The efficiency of enzyme hydrolysis is highly dependent on temperature. The effect of different enzyme hydrolysis temperature on the yield of protein and oil bodies is shown in Fig. 1c. The protein yield decreased after an initial increase, reaching maximum levels $(78.86 \%)$ at $55^{\circ} \mathrm{C}$. The yield of oil bodies followed the same trend, but reached the maximum $(38.86 \%)$ at $50^{\circ} \mathrm{C}$. The protein yield reached maximum levels $(79.91 \%)$ at $80 \mathrm{~min}$, whereas the yield of oil bodies started increasing at $20 \mathrm{~min}$ and plateaued at $80 \mathrm{~min}$ (Fig. 1d). The rate of enzymatic hydrolysis was increased fast initially as the enzyme bound with the substrate. However, as the reaction progressed, the concentration of the substrate and the reaction rate decreased, and the yield of protein oil bodies stabilized.

Cell wall, which consists of cellulose, hemicellulose, and pectin, blocks the release of proteins and oil bodies outside the cell and the penetration of external solvents into the cell. Thus, the degradation of the cell wall is an important step in the extraction of protein and oil bodies. The above results indicate a close correlation of the yield of both protein and oil bodies with the operational parameters, but how the degradation of main components in the peanut
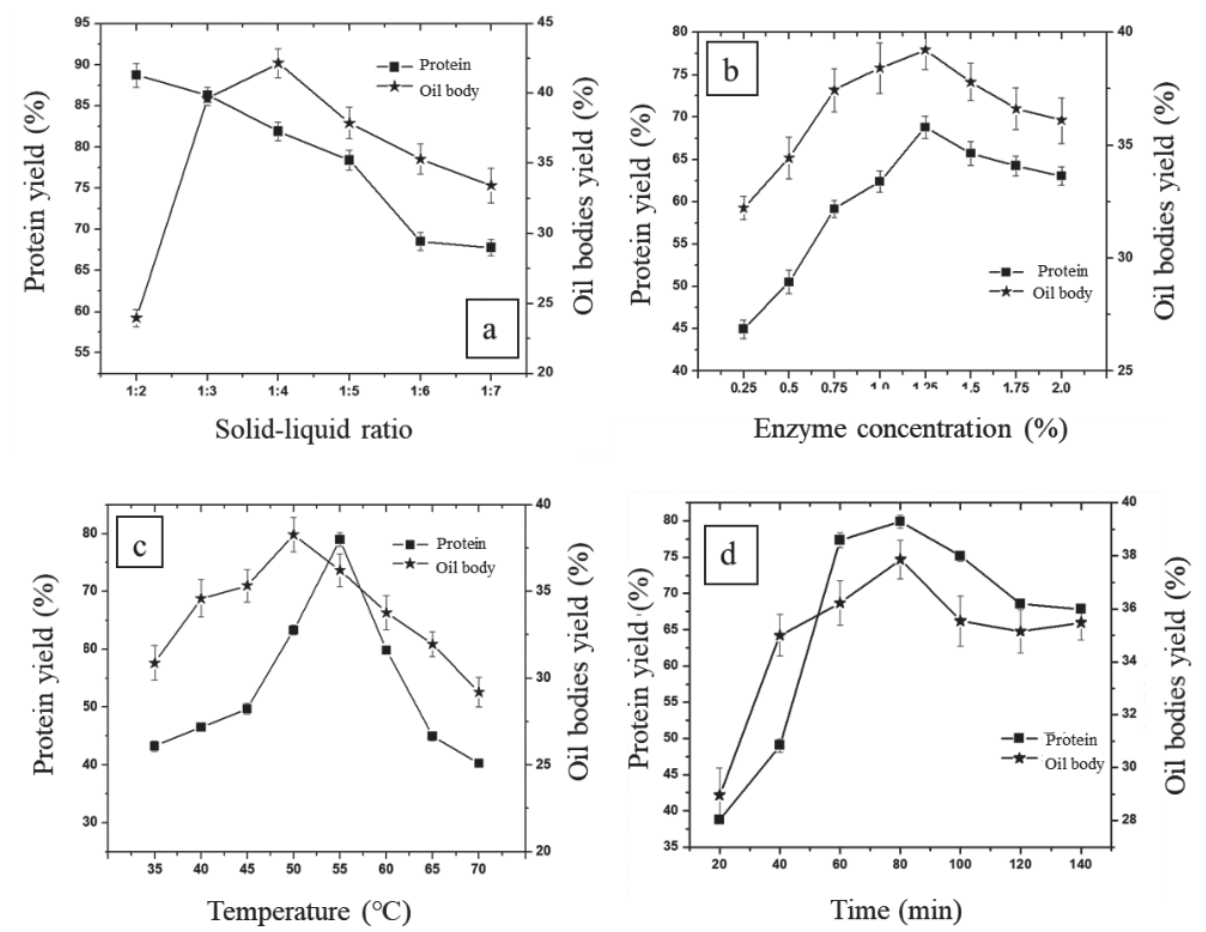

Fig. 1 Effect of enzyme hydrolysis temperature, solid-liquid ratio, enzyme concentration, and enzyme hydrolysis time on the yield of peanut protein and oil bodies. 
cell wall affected the yield of protein and oil bodies was unclear. To address this question, we investigated the effect of Viscozyme ${ }^{\circledast} \mathrm{L}$ on the main compounds of the peanut cell wall.

\subsection{Degradation of the main components in peanut cell wall}

Viscozyme ${ }^{\circledast} \mathrm{L}$, as a complex plant hydrolase, decomposes the cell wall structure. During the process of aqueous enzymatic extraction, the main components in the wall, cellu- lose, hemicellulose and pectin, are progressively degraded, meanwhile protein and oil bodies are gradually released. To elucidate the degradation of the cell wall in the aqueous enzymatic extraction process in more detail, we analyzed the changes in the main cell wall components (Table 1).

The maximum degradation rate of CDTA-soluble pectin (67.4\%), $\mathrm{Na}_{2} \mathrm{CO}_{3}$-soluble pectin $(87.0 \%)$, hemicellulose $(39.1 \%)$, and cellulose $(57.1 \%)$ was reached at solid-liquid ratios of 1:3, 1:4, 1:5, and 1:3, respectively (Table 1). A high protein yield $(86.64 \%)$ and the maximum yield of oil bodies

Table 1 Effects of Viscozyme ${ }^{\circledR} \mathrm{L}$ on peanut cell wall compounds.

\begin{tabular}{|c|c|c|c|c|}
\hline Factors & $\begin{array}{l}\text { CDTA soluble pectin } \\
(\mathrm{mg} / 100 \mathrm{~g})\end{array}$ & $\begin{array}{c}\mathrm{Na}_{2} \mathrm{CO}_{3} \text { soluble pectin } \\
(\mathrm{mg} / 100 \mathrm{~g})\end{array}$ & $\begin{array}{l}\text { Hemicellulose } \\
(\mathrm{mg} / 100 \mathrm{~g})\end{array}$ & $\begin{array}{l}\text { Cellulose } \\
(\mathrm{mg} / 100 \mathrm{~g})\end{array}$ \\
\hline Blank & $18.02 \pm 1.19$ & $12.89 \pm 1.19$ & $74.39 \pm 3.09$ & $468.12 \pm 24.02$ \\
\hline $1: 2$ & $8.97 \pm 0.45 \mathrm{c}$ & $10.78 \pm 0.97 \mathrm{a}$ & $58.13 \pm 7.89 a$ & $451.67 \pm 18.89 \mathrm{a}$ \\
\hline $1: 3$ & $5.72 \pm 0.60 \mathrm{~d}$ & $3.25 \pm 0.37 \mathrm{c}$ & $50.46 \pm 8.43 \mathrm{a}$ & $200.60 \pm 13.78 d$ \\
\hline $1: 4$ & $5.88 \pm 0.57 \mathrm{~d}$ & $2.34 \pm 0.40 \mathrm{~d}$ & $47.46 \pm 7.90 \mathrm{~b}$ & $290.00 \pm 12.78 \mathrm{c}$ \\
\hline 1:5 & $15.06 \pm 0.93 b$ & $2.38 \pm 0.36 \mathrm{~d}$ & $45.33 \pm 7.78 b$ & $446.67 \pm 22.11 \mathrm{a}$ \\
\hline 1:6 & $16.97 \pm 1.00 \mathrm{a}$ & $5.41 \pm 0.45 b$ & $45.42 \pm 7.76 \mathrm{~b}$ & $413.33 \pm 24.05 b$ \\
\hline $1: 7$ & $18.00 \pm 1.25 \mathrm{a}$ & $5.38 \pm 0.49 \mathrm{~b}$ & $56.67 \pm 8.45 \mathrm{a}$ & $456.67 \pm 20.06 \mathrm{a}$ \\
\hline $0.25 \%$ & $15.63 \pm 1.20 \mathrm{a}$ & $10.66 \pm 1.00 \mathrm{a}$ & $50.46 \pm 7.69 a$ & $456.33 \pm 11.45 \mathrm{a}$ \\
\hline $0.50 \%$ & $10.63 \pm 0.97 \mathrm{~b}$ & $7.76 \pm 0.67 b$ & $48.25 \pm 7.07 \mathrm{a}$ & $401.67 \pm 8.05 b$ \\
\hline $0.75 \%$ & $4.59 \pm 0.33 \mathrm{f}$ & $5.09 \pm 0.35 c$ & $27.75 \pm 3.02 d$ & $397.60 \pm 7.89 b$ \\
\hline $1.00 \%$ & $3.41 \pm 0.29 \mathrm{~g}$ & $4.08 \pm 0.07 d$ & $31.42 \pm 3.67 \mathrm{c}$ & $210.00 \pm 7.46 \mathrm{e}$ \\
\hline $1.25 \%$ & $5.44 \pm 0.45 \mathrm{e}$ & $3.09 \pm 0.11 \mathrm{e}$ & $40.34 \pm 6.22 b$ & $223.00 \pm 8.56 \mathrm{~d}$ \\
\hline $1.50 \%$ & $8.78 \pm 0.60 \mathrm{~d}$ & $3.34 \pm 0.23 \mathrm{e}$ & $36.25 \pm 4.00 \mathrm{~b}$ & $373.33 \pm 9.45 \mathrm{c}$ \\
\hline $1.75 \%$ & $9.81 \pm 0.63 \mathrm{c}$ & $5.69 \pm 0.45 c$ & $31.25 \pm 2.05 \mathrm{c}$ & $398.33 \pm 10.09 b$ \\
\hline $2.00 \%$ & $9.78 \pm 0.72 \mathrm{c}$ & $7.13 \pm 0.45 b$ & $33.04 \pm 1.98 \mathrm{c}$ & $371.67 \pm 8.98 \mathrm{c}$ \\
\hline $35^{\circ} \mathrm{C}$ & $16.47 \pm 0.95 b$ & $12.00 \pm 1.23 \mathrm{a}$ & $68.79 \pm 9.19 \mathrm{a}$ & $446.88 \pm 22.51 \mathrm{a}$ \\
\hline $40^{\circ} \mathrm{C}$ & $15.63 \pm 1.10 \mathrm{~b}$ & $4.31 \pm 0.99 \mathrm{e}$ & $42.38 \pm 6.61 \mathrm{c}$ & $354.62 \pm 16.88 \mathrm{~d}$ \\
\hline $45^{\circ} \mathrm{C}$ & $7.13 \pm 0.80 \mathrm{c}$ & $3.91 \pm 0.65 \mathrm{e}$ & $53.06 \pm 8.89 \mathrm{~b}$ & $258.33 \pm 13.56 f$ \\
\hline $50^{\circ} \mathrm{C}$ & $4.41 \pm 0.62 \mathrm{e}$ & $8.53 \pm 0.73 b$ & $58.75 \pm 8.77 \mathrm{~b}$ & $276.67 \pm 15.67 \mathrm{e}$ \\
\hline $55^{\circ} \mathrm{C}$ & $4.78 \pm 0.65 \mathrm{e}$ & $6.34 \pm 0.80 \mathrm{~d}$ & $61.96 \pm 9.29 \mathrm{a}$ & $376.01 \pm 17.76 \mathrm{c}$ \\
\hline $60^{\circ} \mathrm{C}$ & $5.56 \pm 0.77 \mathrm{~d}$ & $7.53 \pm 0.94 \mathrm{c}$ & $64.71 \pm 9.07 \mathrm{a}$ & $421.62 \pm 19.98 b$ \\
\hline $65^{\circ} \mathrm{C}$ & $17.56 \pm 1.21 \mathrm{a}$ & $10.67 \pm 1.03 \mathrm{a}$ & $65.23 \pm 8.97 \mathrm{a}$ & $438.55 \pm 18.33 a$ \\
\hline $70^{\circ} \mathrm{C}$ & $17.87 \pm 1.08 \mathrm{a}$ & $11.02 \pm 0.98 \mathrm{a}$ & $67.79 \pm 9.08 \mathrm{a}$ & $451.62 \pm 19.12 \mathrm{a}$ \\
\hline $20 \mathrm{~min}$ & $14.94 \pm 1.08 \mathrm{a}$ & $11.13 \pm 0.89 \mathrm{a}$ & $69.92 \pm 9.82 \mathrm{a}$ & $438.33 \pm 23.77 \mathrm{a}$ \\
\hline $40 \mathrm{~min}$ & $12.56 \pm 0.96 \mathrm{~b}$ & $8.56 \pm 0.53 b$ & $70.55 \pm 9.94 \mathrm{a}$ & $356.67 \pm 18.15 \mathrm{c}$ \\
\hline $60 \mathrm{~min}$ & $11.84 \pm 0.99 b$ & $6.28 \pm 0.45 \mathrm{~d}$ & $33.25 \pm 1.53 \mathrm{c}$ & $286.67 \pm 13.49 d$ \\
\hline $80 \mathrm{~min}$ & $6.81 \pm 0.65 f$ & $7.47 \pm 0.50 \mathrm{c}$ & $43.96 \pm 5.79 b$ & $220.00 \pm 12.55 \mathrm{e}$ \\
\hline $100 \mathrm{~min}$ & $6.91 \pm 0.59 \mathrm{f}$ & $9.47 \pm 0.87 \mathrm{~b}$ & $46.00 \pm 5.93 b$ & $175.00 \pm 11.75 f$ \\
\hline $120 \mathrm{~min}$ & $8.69 \pm 0.76 \mathrm{~d}$ & $8.78 \pm 0.79 b$ & $48.29 \pm 6.22 b$ & $415.00 \pm 19.99 b$ \\
\hline $140 \mathrm{~min}$ & $7.44 \pm 0.80 \mathrm{e}$ & $8.16 \pm 0.81 b$ & $47.00 \pm 6.03 b$ & $443.33 \pm 21.79 a$ \\
\hline $160 \mathrm{~min}$ & $9.59 \pm 0.77 \mathrm{c}$ & $9.33 \pm 0.88 b$ & $46.71 \pm 5.90 \mathrm{~b}$ & $426.67 \pm 21.06 a$ \\
\hline
\end{tabular}

Note: different letters in each column indicate significant difference $(p<0.05)$ between each factor tested. 
$(42.18 \%)$ were recorded at solid-liquid ratios of $1: 3$ and $1: 4$, at which the degradation rates of CDTA-soluble pectin, $\mathrm{Na}_{2} \mathrm{CO}_{3}$-soluble pectin, and cellulose were the highest (Fig. 1, Table 1). The highest degradation rate of CDTA-soluble pectin $(81.1 \%), \mathrm{Na}_{2} \mathrm{CO}_{3}$-soluble pectin $(76.0 \%)$, hemicellulose $(62.7 \%)$, and cellulose $(55.1 \%)$ were obtained at enzyme concentrations of $1.00,1.25,0.75$, and $1.00 \%$, respectively. The highest protein yield $(77.86 \%)$ and the maximum yield of oil bodies $(35.76 \%)$ was attained at enzyme concentration of $1.25 \%$, at which $\mathrm{Na}_{2} \mathrm{CO}_{3}$-soluble pectin had the best degradation rate (Fig. 1, Table 1). Enzyme hydrolysis parameters had a significant effect on the content of the main cell wall components (Table 1). The maximum degradation rate of CDTA-soluble pectin $(75.5 \%), \mathrm{Na}_{2} \mathrm{CO}_{3}$-soluble pectin $(70.0 \%)$, hemicellulose $(43.0 \%)$, and cellulose $(44.8 \%)$ were reached at enzyme hydrolysis temperatures of $50,45,40$, and $45^{\circ} \mathrm{C}$, respectively. The highest protein yield (78.54\%) and the maximum yield of oil bodies $(37.88 \%)$ was obtained at $55^{\circ} \mathrm{C}$ and $50^{\circ} \mathrm{C}$, respectively, at which CDTA-soluble pectin had the best degradation rate. The degradation rates of CDTA-soluble pectin, $\mathrm{Na}_{2} \mathrm{CO}_{3}$-soluble pectin, hemicellulose, and cellulose were $62.2 \%$ at $80 \mathrm{~min}$ enzyme hydrolysis time, $51.3 \%$ at 60 $\mathrm{min}, 55.3 \%$ at $60 \mathrm{~min}$, and $62.6 \%$ at $100 \mathrm{~min}$, respectively. The maximum protein yield ( $80 \%)$ and the maximum yield of oil bodies $(37.92 \%)$ was recorded when CDTA-soluble pectin had the most optimal degradation rate and the enzyme hydrolysis time of $80 \mathrm{~min}$ (Fig. 1).
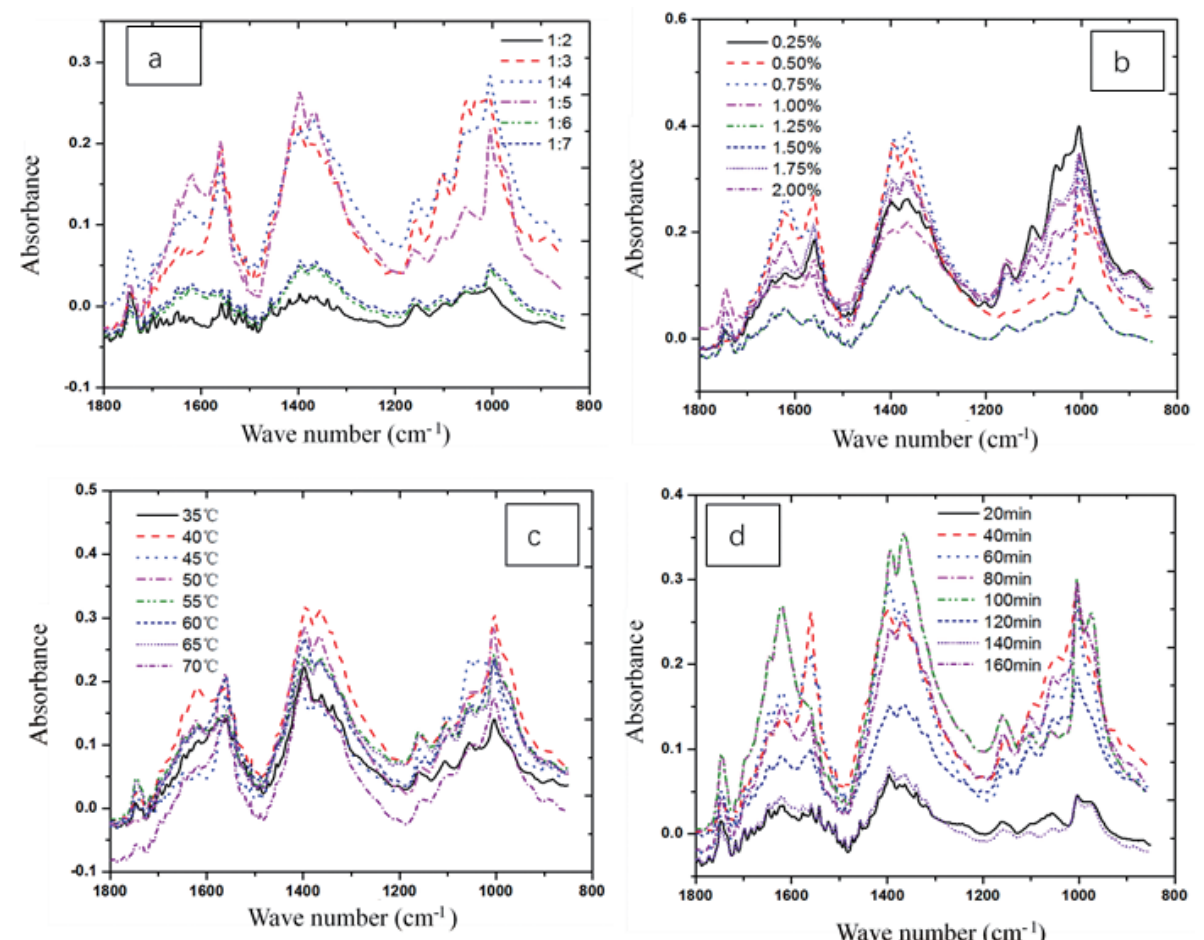

These data suggest a close correlation of the yield of protein and oil bodies with the degradation rates of CDTAsoluble pectin, $\mathrm{Na}_{2} \mathrm{CO}_{3}$-soluble pectin, and cellulose. These results provide a theoretical basis for screening of optimum enzyme conditions for cell wall degradation.

\subsection{FT-IR spectra of cell wall polysaccharides}

The characteristic spectra of pectin, hemicellulose, and cellulose exhibit a strong absorption band in the 1800-800 $\mathrm{cm}^{-1}$ region $^{30)}$. To reveal the effect of enzyme hydrolysis parameters on the main components in the cell wall of peanut, the characteristic wave numbers of cell wall polysaccharides under different extraction conditions were measured within two specific regions, $1800-1200 \mathrm{~cm}^{-1}$ and 1200-800 $\mathrm{cm}^{-1}$. FT-IR spectra are shown in Figs. 2-5, and the main characteristic wave numbers measured in the present study and infrared spectral wave numbers of cell wall polysaccharides in available literature are listed in Table 2.

Cellulose is a linear homopolymer composed of $1,4-$ linked $\beta$-D-Glc $p$ units (1,4-linked $\beta$-D-glucan), while hemicellulose is a polymer composed of different types of monosaccharides such as pentose and hexose (e.g. xylose, arabinose, and galactose). Cellulose and hemicellulose are combined by hydrogen bond forming the network structure of cell wall which is filled with pectin ${ }^{311}$. In the case of plant cell wall, polysaccharides are bonded with each other, which may cause the slight shift of characteristic bands ${ }^{27)}$.

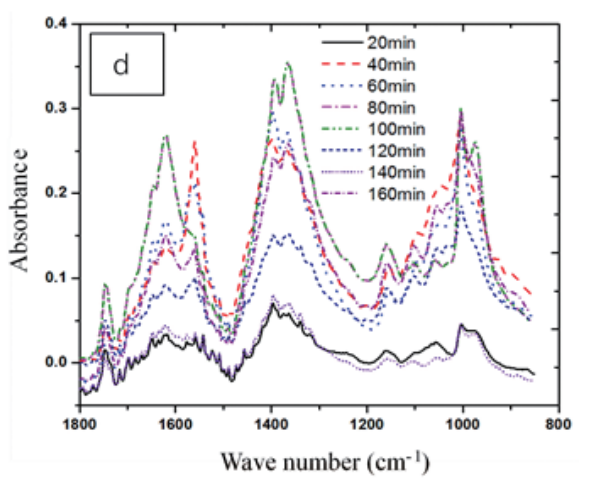

Fig. 2 FT-IR spectra of cellulose under different extraction conditions.

(a: solid-liquid ratio; b: enzyme concentration; c: enzyme hydrolysis temperature; d: enzyme hydrolysis time) 

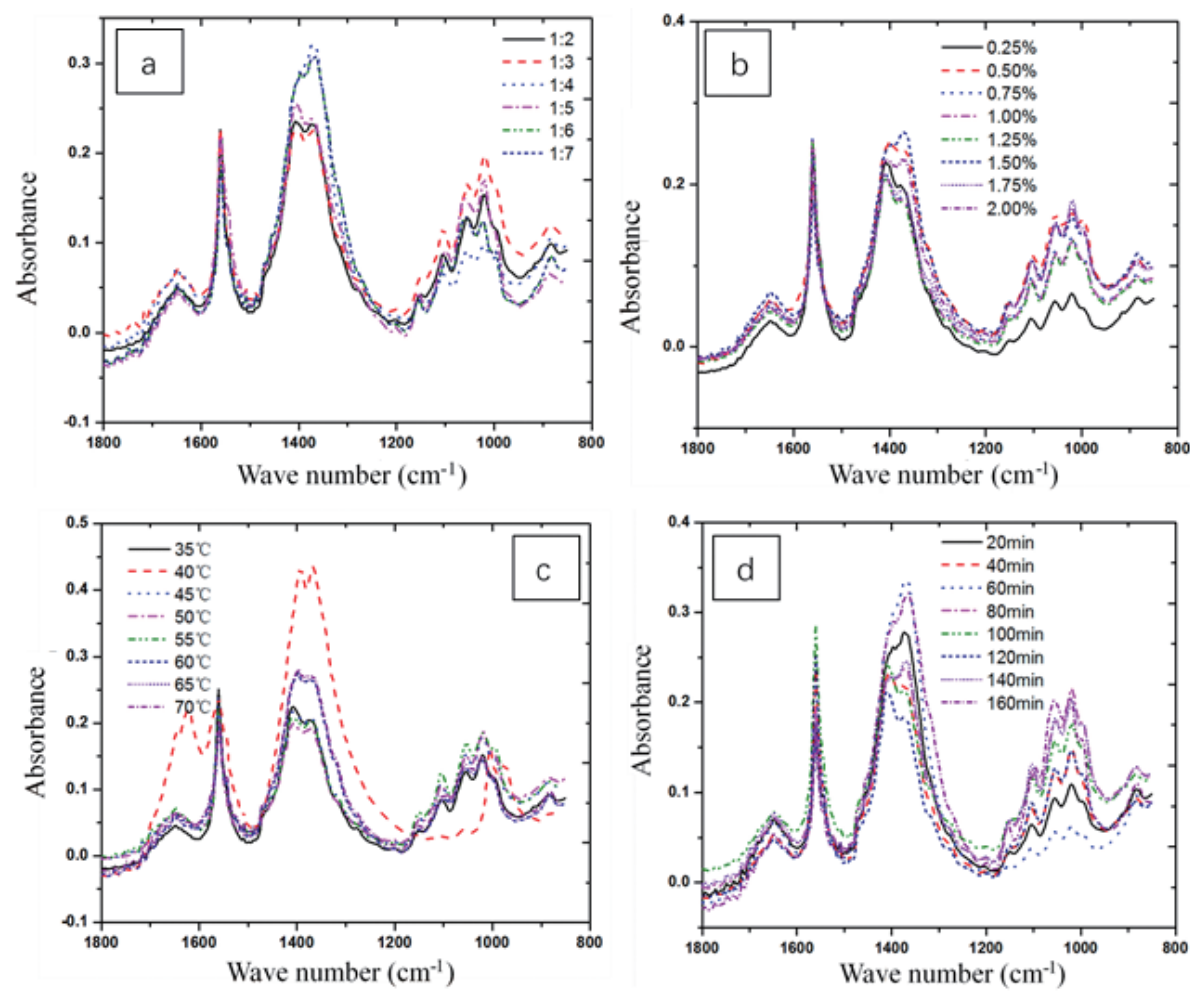

Fig. 3 FT-IR spectra of hemicellulose under different extraction conditions.

(a: solid-liquid ratio; b: enzyme concentration; c: enzyme hydrolysis temperature; d: enzyme hydrolysis time)
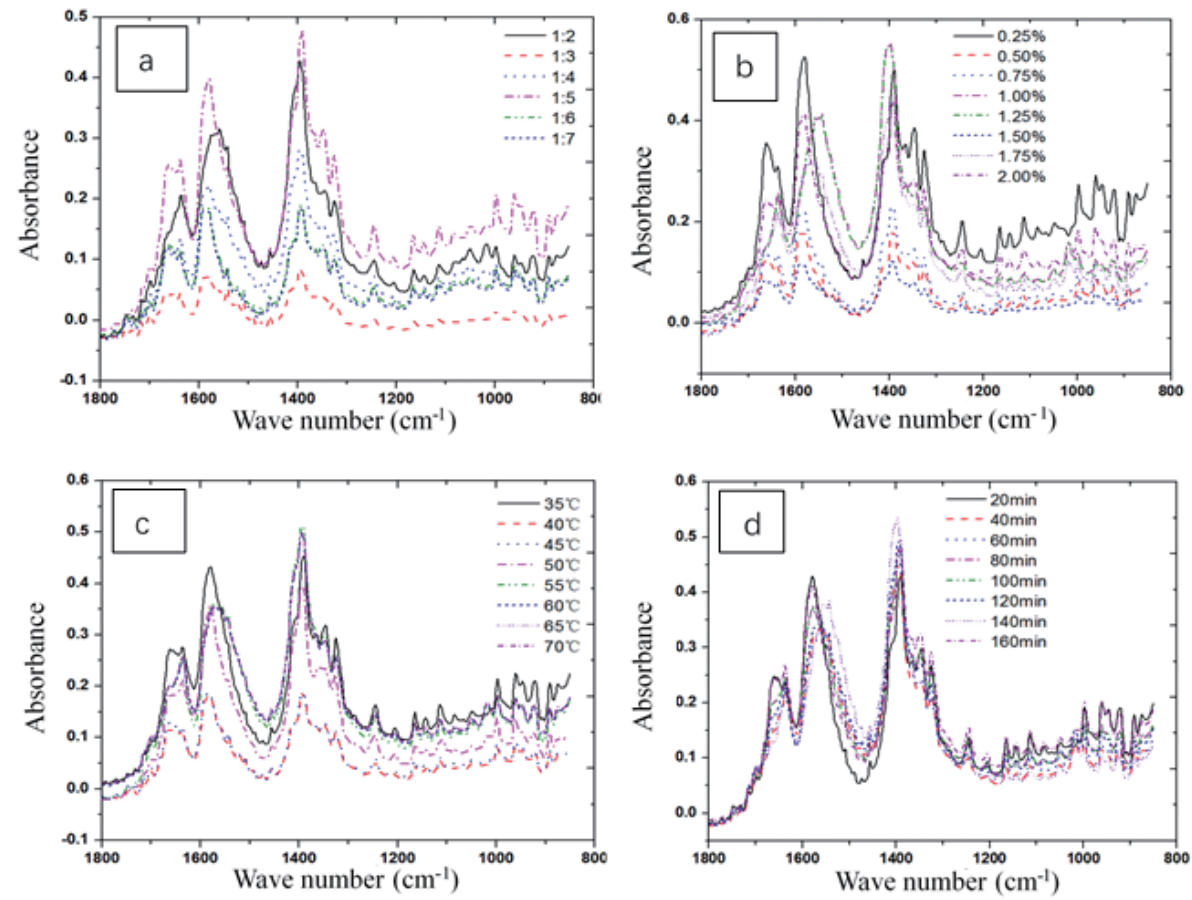

Fig. 4 FT-IR spectra of CDTA soluble pectin under different extraction conditions.

(a: solid-liquid ratio; b: enzyme concentration; c: enzyme hydrolysis temperature; d: enzyme hydrolysis time) 

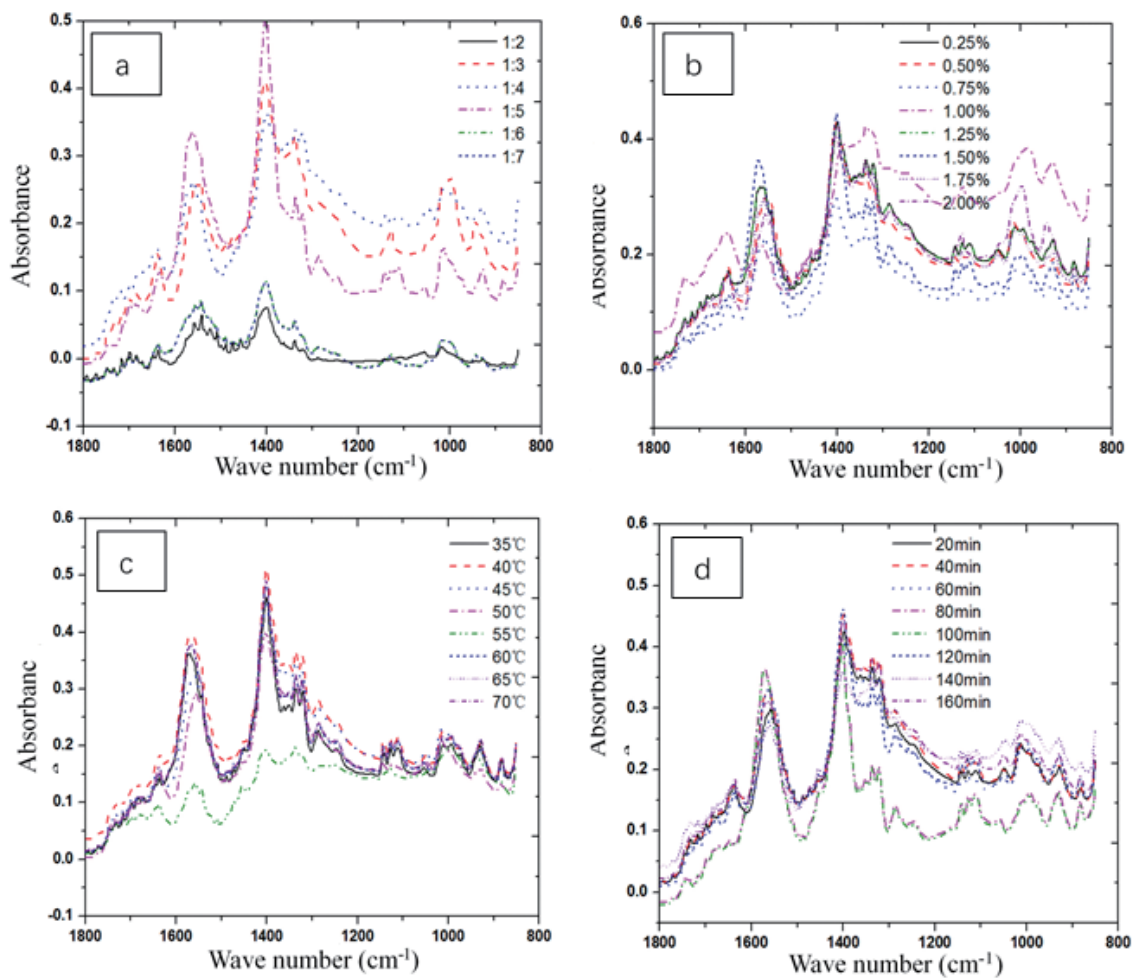

Fig. 5 FT-IR spectra of $\mathrm{Na}_{2} \mathrm{CO}_{3}$-soluble pectin under different extraction conditions.

(a: solid-liquid ratio; b: enzyme concentration; c: enzyme hydrolysis temperature; d: enzyme hydrolysis time)

Table 2 Absorption wave numbers obtained by FT-IR for assignment of cell wall polysaccharides.

\begin{tabular}{|c|c|c|c|c|}
\hline 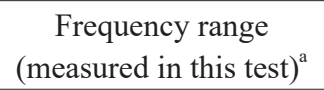 & $\begin{array}{l}\text { Frequency range } \\
\text { (literature) }^{\mathrm{b}}\end{array}$ & Assignment $^{\mathrm{c}}$ & Origin $^{\mathrm{d}}$ & Comment \\
\hline $1739.7(\mathrm{P})$ & $1745-1740$ & $\begin{array}{l}\mathrm{C}=\mathrm{O} \text { stretching } \\
\text { vibration of alkyl ester }\end{array}$ & Pectin & CWM and CDTA \\
\hline $1610.5(\mathrm{P})$ & $1630-1600$ & $\begin{array}{l}\text { COO-antisymmetric } \\
\text { stretching }\end{array}$ & $\begin{array}{c}\text { Polygalacturonic acid, } \\
\text { carboxylate (pectin ester group) }\end{array}$ & $\begin{array}{l}\text { Mainly CWM and } \\
\text { CDTA residue }\end{array}$ \\
\hline $\begin{array}{c}1361.7,1369.4,1361.7 \\
1371.3(\mathrm{XG}, \mathrm{C})\end{array}$ & 1370 & $\mathrm{CH} 2$ bending & Xyloglucan, Cellulose & $\begin{array}{l}\text { KOH residue } \\
\text { All residue }\end{array}$ \\
\hline $\begin{array}{c}1029.9(\mathrm{C}) \\
1313.5,1317.3(\mathrm{C})\end{array}$ & 1317 & $\begin{array}{l}\mathrm{CH} 2 \text { symmetric } \\
\text { bending }\end{array}$ & Cellulose & $\mathrm{KOH}$ residue \\
\hline $\begin{array}{c}1230.5,1240.2,1265.3 \\
1267.2(\mathrm{P})\end{array}$ & 1243 & $\mathrm{C}-\mathrm{O}$ stretching & Pectin & $\mathrm{KOH}$ residue \\
\hline $1139.9(\mathrm{XG})$ & 1130 & $\begin{array}{c}\mathrm{O}-\mathrm{C}-\mathrm{O} \text { asymmetric } \\
\text { stretching }\end{array}$ & Xyloglucan (glycosidic link) & $\begin{array}{l}\text { CWM and CDTA } \\
\text { residue }\end{array}$ \\
\hline $1035.7,1037.7(\mathrm{XG})$ & 1042 & $\begin{array}{c}\mathrm{C}-\mathrm{O} \text { stretching, } \mathrm{C}-\mathrm{C} \\
\text { stretching }\end{array}$ & Xyloglucan (ring) & None \\
\hline $1029.9(\mathrm{C})$ & 1030 & $\begin{array}{l}\mathrm{C}-\mathrm{O} \text { stretching, } \mathrm{C}-\mathrm{C} \\
\text { stretching }\end{array}$ & Cellulose (C6-H2-O6) & None \\
\hline $1010.7,1014.5(\mathrm{P})$ & 1019 & $\begin{array}{l}\mathrm{C}-\mathrm{O} \text { stretching, } \mathrm{C}-\mathrm{C} \\
\text { stretching }\end{array}$ & Pectin $(\mathrm{C} 2-\mathrm{C} 3, \mathrm{C} 2-\mathrm{O} 2, \mathrm{C} 1-\mathrm{O} 1)$ & $\begin{array}{l}\text { CWM and CDTA } \\
\text { residue }\end{array}$ \\
\hline $\begin{array}{c}997.2,1008.7 \\
1010.7(\mathrm{C})\end{array}$ & 1000 & $\begin{array}{l}\mathrm{C}-\mathrm{O} \text { stretching, } \mathrm{C}-\mathrm{C} \\
\text { stretching }\end{array}$ & Cellulose (C6-H2-O6) & $\begin{array}{l}\mathrm{Na}_{2} \mathrm{CO}_{3} \text { residue } \\
\text { (potato) }\end{array}$ \\
\hline
\end{tabular}

Note: ${ }^{a}$ the main wave numbers obtained in the present study; ${ }^{\mathrm{b}}$ the main wave numbers reported in the literature ${ }^{30-34)}{ }^{\mathrm{c}}$ functional groups; ${ }^{\mathrm{d}}$ molecules of the functional groups. CWM, cell wall material; CDTA, 2-cyclohexanediamine- $N, N, N N^{\prime}, N{ }^{\prime}$-acetic acid; C, cellulose; P, pectin; XG, xyloglucan. 
Slight differences were observed in the characteristic wave numbers of cell wall polysaccharides measured herein and those reported in previous studies ${ }^{32-36)}$ (Table 2).

The effect of different extraction conditions (solid-liquid ratio, enzyme concentration, enzyme hydrolysis temperature, and enzyme hydrolysis time) on FT-IR spectra of celluloses are presented in Fig. 2. The main characteristic wave numbers of cellulose remained unchanged under different extraction conditions, but the absorbance, which denotes the content of characteristic wave numbers, varied significantly. Examples of FT-IR spectra of cellulose under different solid-liquid ratio are shown in Fig. 2a, cellulose had same characteristic wave numbers. However, characteristic bands of celluloses at solid-liquid ratio 1:3, 1:4, and 1:5 were sharper and more intensive compared to that at solid-liquid ratio 1:2. The solid-liquid ratio, enzyme concentration, enzyme hydrolysis temperature, and enzyme hydrolysis time exhibited a different degree of influence on the cellulose characteristic wave numbers, and changes of characteristic bands were corresponding to the acting sites of Viscozyme ${ }^{\circledR}$ L on cellulose. Similar results were observed for hemicellulose, CDTA-soluble pectin, and $\mathrm{Na}_{2} \mathrm{CO}_{3}$-Soluble pectin (Figs. 3-5).

\subsection{PCA of characteristic wave numbers of cell wall poly- saccharides}

The PCA scatter plots of the FT-IR spectra of cell wall polysaccharides in the $1800-800 \mathrm{~cm}^{-1}$ region is shown in
Fig. 6. The changes of infrared spectroscopy in the main components of the cell wall (cellulose, hemicellulose, and pectin) under different extraction conditions were explained by PC1 and PC2. PC1 and PC2 indicated that cell wall residues were grouped or scattered in group along the PC2 axis and PC1 axis, respectively. Not only reflected difference between groups of cellulose, hemicellulose, and pectin, but also reflected differences in the group of cellulose, hemicellulose, and pectin affected by solid-liquid ratio, enzyme concentration, enzyme hydrolysis temperature, and enzyme hydrolysis time.

The scores scatter plots PC1 (explained $81.59 \%$ of variability) and PC2 (explained $7.84 \%$ of variability)were used to obtain separation of each group of cell wall polysaccharides in $1800-800 \mathrm{~cm}^{-1}$ region at different solid-liquid ratios (Fig. 6a). The scores scatter plot PC1 vs. PC2 indicates that the cell wall polysaccharides are grouped along the PC2 axis and scattered along the PC1 axis. The tendency for the location of scores of cell wall polysaccharides was going from positive to negative values along the PC1 axis, indicating that the solid-liquid ratio exerted a strong effect on characteristic wave numbers of CDTA-soluble pectin, $\mathrm{Na}_{2} \mathrm{CO}_{3}$-soluble pectin, cellulose, and hemicellulose. The high coefficients of infrared wave values in the component matrix (Table 3) indicated that the corresponding group played a larger role in the enzymatic hydrolysis of the cell wall. The characteristic wave numbers of cellulose influenced by liquid-solid ratio were 997.2, 1008.7, 1010.7,
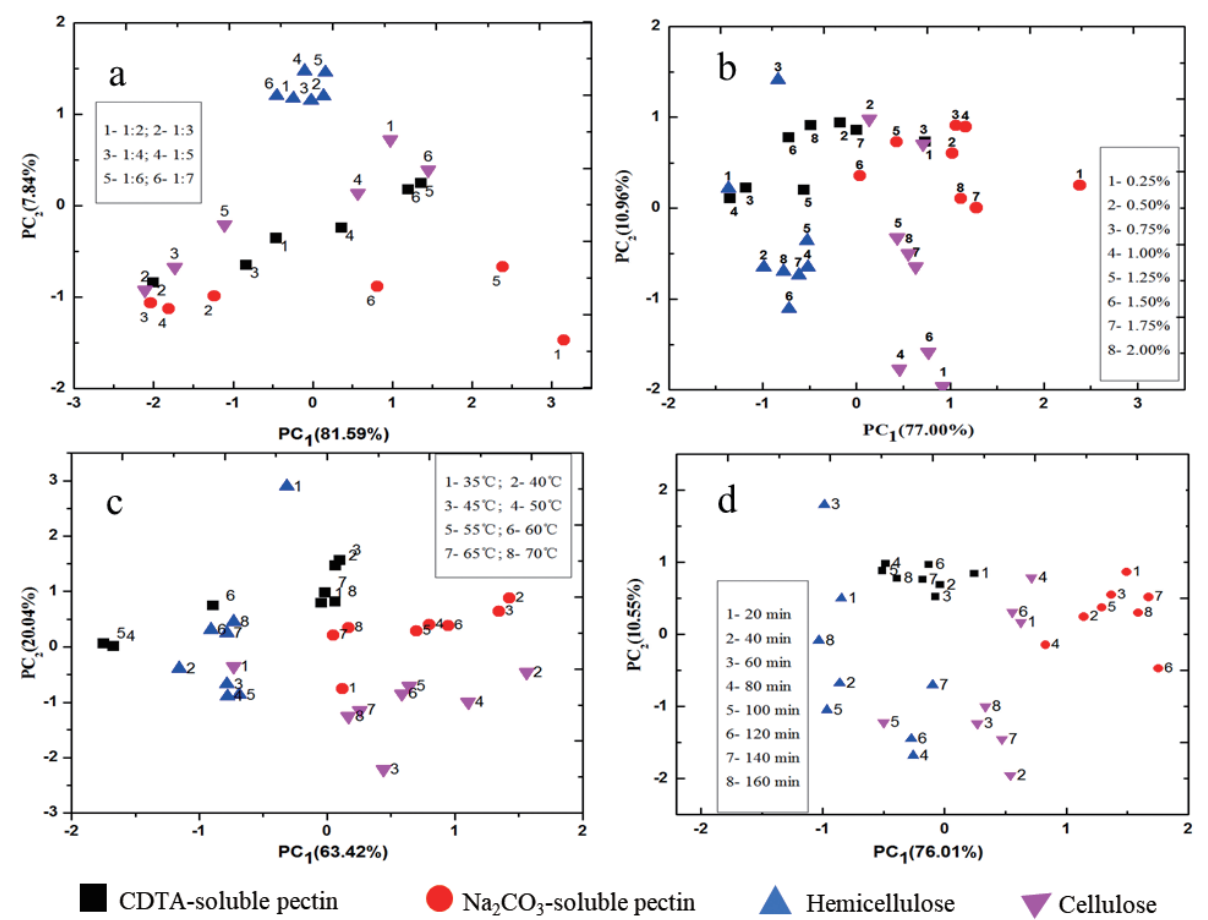

Fig. 6 PCA score scatter plots of peanut cell wall FT-IR spectra in the $1800-800 \mathrm{~cm}^{-1}$ region for pectin, hemicellulose, and cellulose under different extraction conditions.

(a: solid-liquid ratio; b: enzyme concentration; c: enzyme hydrolysis temperature; d: enzyme hydrolysis time) 
Table 3 Component matrix of principal component analysis.

\begin{tabular}{|c|c|c|c|c|c|c|c|c|c|}
\hline \multicolumn{2}{|c|}{ Wave length } & \multicolumn{2}{|c|}{$\begin{array}{l}\text { Solid-liquid ratio/ } \\
\mathrm{g} / \mathrm{mL}\end{array}$} & \multicolumn{2}{|c|}{ enzymatic content/ $\%$} & \multicolumn{2}{|c|}{$\begin{array}{l}\text { enzyme hydrolysis } \\
\text { temperature } /{ }^{\circ} \mathrm{C}\end{array}$} & \multicolumn{2}{|c|}{$\begin{array}{l}\text { enzyme hydrolysis } \\
\text { time /min }\end{array}$} \\
\hline & & $\mathrm{PC}_{1}$ & $\mathrm{PC}_{2}$ & $\mathrm{PC}_{1}$ & $\mathrm{PC}_{2}$ & $\mathrm{PC}_{1}$ & $\mathrm{PC}_{2}$ & $\mathrm{PC}_{1}$ & $\mathrm{PC}_{2}$ \\
\hline \multirow{8}{*}{ Celluloses } & 997.159 & 0.928 & -0.292 & 0.945 & -0.179 & 0.961 & 0.036 & 0.910 & -0.287 \\
\hline & 1008.732 & 0.895 & -0.381 & 0.914 & -0.311 & 0.936 & 0.109 & 0.879 & -0.411 \\
\hline & 1010.660 & 0.911 & -0.386 & 0.915 & -0.326 & 0.946 & 0.123 & 0.908 & -0.396 \\
\hline & 1029.948 & 0.844 & -0.517 & 0.698 & -0.591 & 0.897 & 0.319 & 0.834 & -0.491 \\
\hline & 1313.473 & 0.965 & 0.235 & 0.832 & 0.498 & 0.973 & -0.076 & 0.951 & 0.270 \\
\hline & 1317.330 & 0.952 & 0.273 & 0.805 & 0.521 & 0.965 & -0.102 & 0.937 & 0.309 \\
\hline & 1361.691 & 0.838 & 0.302 & 0.641 & 0.696 & 0.858 & 0.329 & 0.824 & 0.312 \\
\hline & 1369.406 & 0.809 & 0.305 & 0.602 & 0.704 & 0.843 & 0.351 & 0.781 & 0.332 \\
\hline \multirow{6}{*}{$\begin{array}{c}\text { Hemicellu- } \\
\text { loses }\end{array}$} & 960.513 & 0.913 & 0.032 & 0.740 & 0.257 & 0.913 & -0.173 & 0.884 & 0.066 \\
\hline & 1035.734 & 0.852 & -0.509 & 0.723 & -0.596 & 0.899 & 0.292 & 0.855 & -0.475 \\
\hline & 1037.663 & 0.858 & -0.496 & 0.738 & -0.583 & 0.905 & 0.279 & 0.864 & -0.461 \\
\hline & 1139.886 & 0.915 & 0.145 & 0.719 & 0.206 & 0.936 & -0.323 & 0.924 & 0.143 \\
\hline & 1361.691 & 0.838 & 0.302 & 0.644 & 0.695 & 0.858 & 0.329 & 0.824 & 0.312 \\
\hline & 1371.335 & 0.812 & 0.310 & 0.608 & 0.701 & 0.844 & 0.346 & 0.779 & 0.343 \\
\hline \multirow{8}{*}{ Pectin } & 1010.660 & 0.911 & -0.386 & 0.923 & -0.280 & 0.946 & 0.123 & 0.908 & -0.396 \\
\hline & 1014.518 & 0.908 & -0.397 & 0.873 & -0.421 & 0.946 & 0.165 & 0.912 & -0.364 \\
\hline & 1230.537 & 0.884 & 0.287 & 0.903 & -0.204 & 0.897 & -0.409 & 0.907 & 0.253 \\
\hline & 1240.181 & 0.876 & 0.313 & 0.894 & -0.041 & 0.889 & -0.421 & 0.897 & 0.301 \\
\hline & 1265.254 & 0.915 & 0.249 & 0.928 & 0.123 & 0.926 & -0.315 & 0.925 & 0.217 \\
\hline & 1267.183 & 0.917 & 0.243 & 0.932 & 0.098 & 0.928 & -0.304 & 0.926 & 0.210 \\
\hline & 1610.499 & 0.691 & 0.329 & 0.719 & 0.063 & 0.766 & -0.241 & 0.669 & 0.285 \\
\hline & 1739.725 & 0.826 & 0.137 & 0.628 & -0.470 & 0.805 & -0.433 & 0.829 & 0.030 \\
\hline
\end{tabular}

1313.5, and $1317.3 \mathrm{~cm}^{-1}$ and they were related to the C-O stretching, $\mathrm{C}-\mathrm{C}$ stretching, and the $\mathrm{CH}_{2}$ symmetrical bending of cellulose. The characteristic wave numbers of hemicellulose were 960.5, 1037.7, and $1139.9 \mathrm{~cm}^{-1}$, and they were assigned to the $\mathrm{C}-\mathrm{O}$ stretching, $\mathrm{C}-\mathrm{C}$ stretching, and $\mathrm{O}-\mathrm{C}-\mathrm{O}$ asymmetrical bending of hemicellulose. Furthermore, the characteristic wave numbers of pectin were $1010.7,1014.5,1265.3$, and $1267.2 \mathrm{~cm}^{-1}$, and they acted on the $\mathrm{C}-\mathrm{O}$ stretching and C-C stretching of pectin.

The scores scatter plot shown in Figs. 6b-d allow the distinction of each group of cell wall polysaccharides in $1800-800 \mathrm{~cm}^{-1}$ region at different enzyme concentrations, enzyme hydrolysis temperatures, and enzyme hydrolysis times along the $\mathrm{PC} 1$ axis, which corresponds to 77.00 , 63.42 , and $76.01 \%$ of the variability contained in the FT-IR spectra, respectively. The scores scatter plot PC1 vs. PC2 indicates that the cell wall polysaccharides are grouped along the $\mathrm{PC} 2$ axis and scattered along the $\mathrm{PC} 1$ axis. The scores of cellulose and $\mathrm{Na}_{2} \mathrm{CO}_{3}$-soluble pectin lay on the positive side of PC1 scores, while CDTA-soluble pectin and hemicellulose were on the negative side of PC1. Clear grouping of cell wall polysaccharides was obtained under different enzyme concentrations, enzyme hydrolysis temperatures, and enzyme hydrolysis times, indicating that enzymatic conditions had strong effect on cell wall polysaccharides. The characteristic wave numbers of cellulose influenced by enzyme concentration were 997.2, 1010.7, $1313.5,1317.3 \mathrm{~cm}^{-1}$, and they acted on the C-O stretching, C-C stretching, and $\mathrm{CH}_{2}$ symmetrical bending of cellulose; the characteristic wave numbers of hemicellulose were 960.5 and $1139.9 \mathrm{~cm}^{-1}$, and they acted on the O-C-O asymmetrical bending of hemicellulose; the characteristic wave numbers of pectin were 1010.7, 1230.5, 1265.3, and 1267.2 $\mathrm{cm}^{-1}$, and they acted on the C-O stretching and C-C stretching of pectin (Fig. $6 \mathrm{~b}$ and Table 3 ). The characteristic wave numbers of cellulose influenced by enzyme hydrolysis temperature were 997.2, 1008.7, and $1010.7 \mathrm{~cm}^{-1}$; they acted on the C-O stretching and C-C stretching of cellulose; the characteristic wave numbers of hemicellulose were $960.5,1037.7$, and $1139.9 \mathrm{~cm}^{-1}$, and they acted on the $\mathrm{C}-\mathrm{O}$ stretching, C-C stretching, and O-C-O asymmetrical bending of hemicellulose; the characteristic wave 
numbers of pectin were $1010.7,1230.5,1265.3$, and 1267.2 $\mathrm{cm}^{-1}$, and they acted on the C-O stretching and C-C stretching of pectin (Fig. 6b and Table 3). As shown in Fig. 6d and Table 3, the characteristic wave numbers of cellulose influenced by enzymatic time were 997.2, 1010.7, 1313.5 , and $1317.3 \mathrm{~cm}^{-1}$, which acted on the C-O stretching, C-C stretching, and $\mathrm{CH}_{2}$ symmetrical bending of cellulose; the characteristic wave number of hemicellulose was $1139.9 \mathrm{~cm}^{-1}$, which acted on the O-C-O asymmetrical bending of hemicellulose; the characteristic wave numbers of pectin were 1010.7, 1014.5, 1230.5, 1265.3, and 1267.2 $\mathrm{cm}^{-1}$, which acted on the C-O stretching and C-C stretching of pectin.

The above results indicate that Viscozyme ${ }^{\circledR} \mathrm{L}$ acted on the $\mathrm{C}-\mathrm{O}$ stretching, $\mathrm{C}-\mathrm{C}$ stretching, and $\mathrm{CH}_{2}$ symmetrical bending of cellulose, the C-O stretching and O-C-O asymmetrical bending of hemicellulose, and the C-O stretching and C-C stretching of pectin during the process of aqueous enzymatic extraction(Fig. 7).

\subsection{The mechanism of aqueous enzymatic extraction of protein and oil bodies}

The mechanism of the protein and oil body extraction through the enzymatic hydrolysis of the peanut cell wall is presented schematically in Fig. 8. Proteins and oils are present in peanut cotyledon cells in the form of protein bodies and oil bodies. The cell wall, which is composed of cellulose, hemicellulose, and pectin, maintains the cell structure and inhibits the release of proteins and oils. In the aqueous enzymatic extraction process, mechanical crushing is an important step that destroys the peanut cell wall and promotes the release of proteins and oil bodies.
We used the conventional dry crushing in this study to break the chain structure of the cell wall and decrease the peanut particle size. However, dry crushing destroyed only a part of peanut cells, and therefore not all protein and oil bodies were released. In contrast, Viscozyme ${ }^{\circledR} \mathrm{L}$ degraded sufficiently the structure of the cell wall by acting on the $\mathrm{C}-\mathrm{O}$ stretching, $\mathrm{C}-\mathrm{C}$ stretching, and $\mathrm{CH}_{2}$ symmetrical bending of cellulose, the $\mathrm{C}-\mathrm{O}$ stretching and O-C-O asymmetrical bending of hemicellulose, and the $\mathrm{C}-\mathrm{O}$ stretching and $\mathrm{C}-\mathrm{C}$ stretching of pectin, and thus facilitated the release of oil bodies and proteins from peanut cells. After centrifugation of the extract, which contained proteins, oil bodies, and the enzymatic hydrolysate of cell wall polysaccharides, oil bodies exist in the upper layer of the aqueous phase, while proteins and enzymatic hydrolysate are in the aqueous phase.

\section{Conclusions}

The extraction of oil bodies and peanut protein was closely related to the degree to which the main components of the peanut cell wall were degraded. The yield of peanut protein and oil bodies was positively correlated to the degradation rate of CDTA-soluble pectin, $\mathrm{Na}_{2} \mathrm{CO}_{3}$-soluble pectin, and cellulose. Viscozyme ${ }^{\circledR} \mathrm{L}$ degraded the cellulose, hemicellulose, and pectin molecules and destroyed the structure of the cell wall to a greater extent compared with mechanical degradation. Viscozyme ${ }^{\circledR} \mathrm{L}$ acted on the $\mathrm{C}-\mathrm{O}$ stretching, $\mathrm{C}-\mathrm{C}$ stretching, and $\mathrm{CH}_{2}$ symmetrical bending of cellulose, the C-O stretching and O-C-O asymmetrical bending of hemicellulose, and the C-O stretching
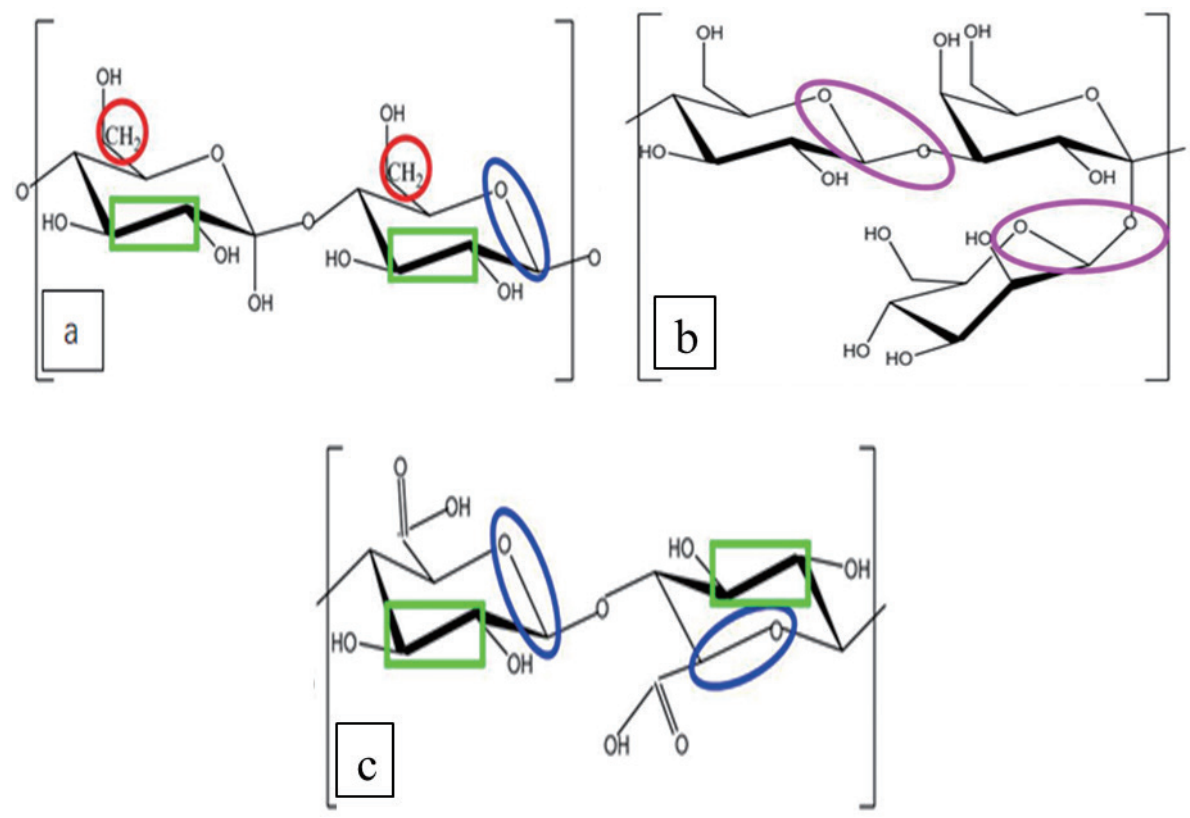

Fig. 7 Molecular structure of cellulose (a), pectin (b), and hemicellulose (c). 


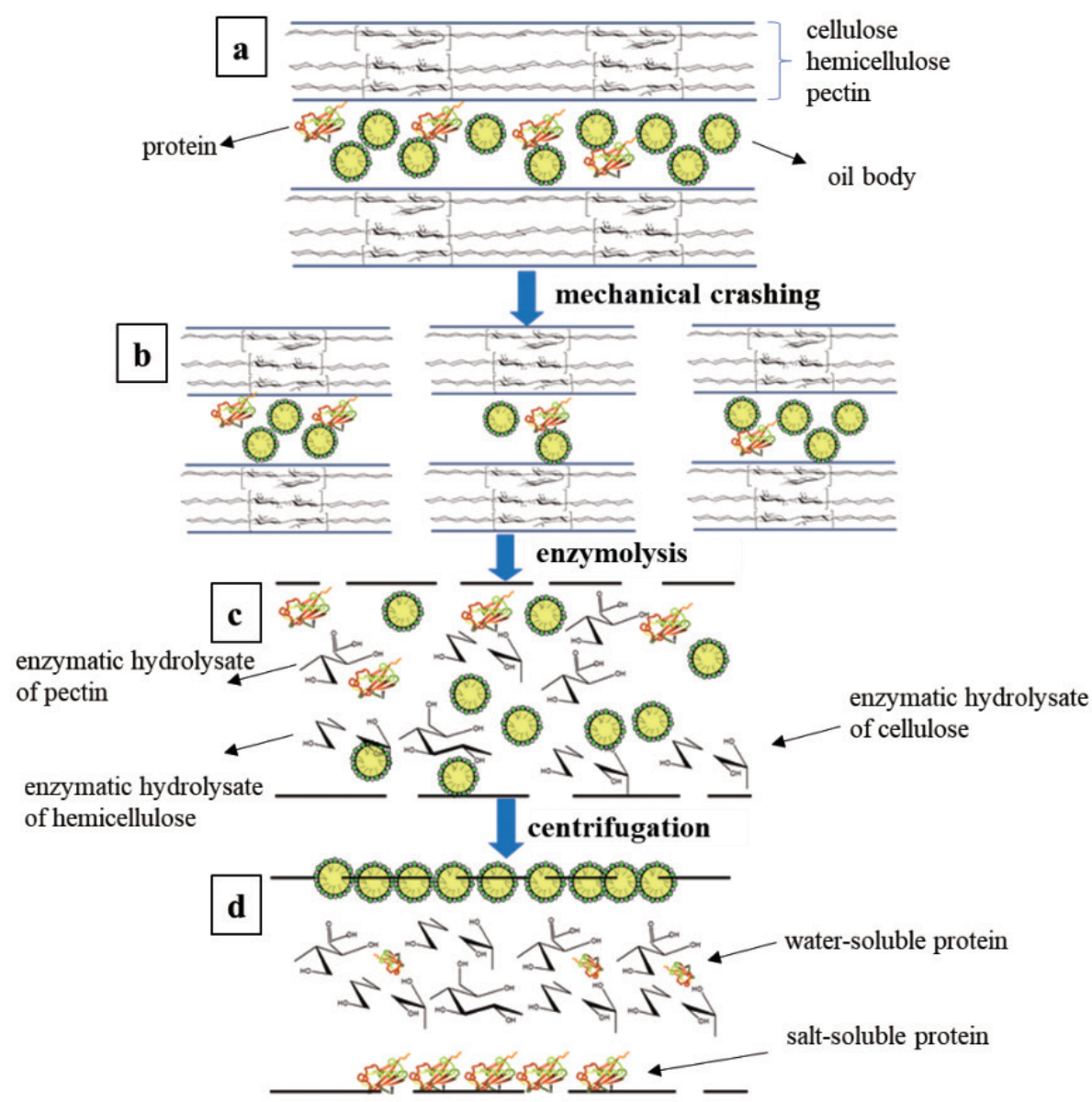

Fig. 8 Schematic diagram of the mechanism of enzymatic extraction of proteins and oil bodies from peanut seeds.

and C-C stretching of pectin. This, in turn, facilitated the release of oil bodies and proteins from the cells. The mechanism of cell wall degradation was preliminarily discussed by analyzing the changes in the structure of cell wall polysaccharides and the key sites of Viscozyme ${ }^{\circledR} \mathrm{L}$ action on peanut cell wall during enzymatic hydrolysis. These data will provide theoretical basis for further research on the mechanism of aqueous enzymatic extraction.

\section{Acknowledgements}

This study was supported by the National Natural Science Foundation of China (21676073).

\section{Author Contributions}

C. Liu and L. Hao designed and conducted the experiments, performed data analysis, and wrote the manuscript. F. Chen supervised the study and helped to initiate the project. T. Zhu revised the manuscript.

\section{Conflict of Interest}

We declare that we have no conflict of interest.

\section{References}

1) Liu, J.J.; Gasmalla, M.A.A.; Li, P. Enzyme-assisted extraction processing from oilseeds: Principle, processing and application. Innov. Food Sci. Emerg. Technol. 35, 184-193 (2016).

2) Li, Y.; Qi, B.K.; Sui, X. Study on high pressure steam demulsification of peanut oil extracted by enzyme-assisted aqueous extraction. China Oils and Fats 41 (7), 6-9 (2016).

3) Mat Yusoff, M.; Gordon, M.H.; Niranjan, K. Aqueous enzyme assisted oil extraction from oilseeds and emulsion de-emulsifying methods: a review. Trends Food Sci. Technol. 41, 60-82(2015).

4) Campbell, K.A.; Glatz, C.E. Advances in aqueous extraction processing of soybeans. J. Am. Oil Chem. Soc. 88, 449-465(2011).

5) Latif, S.; Anwar, F.; Hussain, A.I. Aqueous enzymatic process for oil and protein extraction from Moringa 
oleifera seed. Eur. J. Lipid Sci. Technol. 113, 10121018(2011).

6) Balvardi, M.; Rezaei, K.; Mendiola, J.A. Optimization of the aqueous enzymatic extraction of oil from Iranian wild almond. J. Am. Oil Chem. Soc. 92, 985-992 (2015).

7) Bisht, T.S.; Sharma, S.K.; Sati, R.C. Improvement of efficiency of oil extraction from wild apricot kernels by using enzymes. J. Food Sci. Technol. 52, 1543-1551 (2015).

8) Szydłowska-Czerniak, A.; Karlovits, G.; Hellner, G. Effect of enzymatic and hydrothermal treatments of rapeseeds on quality of the pressed rapeseed oils: part II. Oil yield and oxidative stability. Process Biochem. 45, 247-258(2010).

9) Zúñiga, M.E.; Soto, C.; Mora, A. Enzymic pre-treatment of Guevina avellana mol oil extraction by pressing. Process Biochem. 39, 51-57 (2003).

10) Gaur, R.; Sharma, A.; Khare, S.K. A novel process for extraction of edible oils: Enzyme assisted three phase partitioning (EATPP). Bioresour. Technol. 98, 696699 (2007).

11) Barros, A.S.; Mafra, I.; Ferreira, D. Determination of the degree of methylesterification of pectic polysaccharides by FT-IR using an outer product PLS1 regression. Carbohydr. Polym. 50, 85-94 (2002).

12) Ferreira, D.; Barros, A.; Coimbra, M.A. Use of FT-IR spectroscopy to follow the effect of processing in cell wall polysaccharide extracts of a sun-dried pear. Carbohydr. Polym. 45, 175-182 (2001).

13) Coimbra, M.A.; Barros, A.; Barros, M. Multivariate analysis of uronic acid and neutral sugars in whole pectic samples by FT-IR spectroscopy. Carbohydr. Polym. 37, 241-248 (1998).

14) Fry, S.C. Growing Plant Cell Wall Chemical \& Metabolic Analysis, Longman, Harlow (1988).

15) He, X.Q. Multivariate statistical analysis, $4^{\text {th }}$ ed. China Renmin University Press, Beijing, China, pp. 114-128(2015).

16) Alonso-Simón, A.; Encina, A.E.; García-Angulo, P. FTIR spectroscopy monitoring of cell wall modifications during the habituation of bean(Phaseolus vulgaris L.) callus cultures to dichlobenil. Plant Science (Oxford) 167, 1280-1281 (2004).

17) Gnanasambandam, R.; Proctor, A. Determination of pectin degree of esterification by diffuse reflectance Fourier transform infrared spectroscopy. Food Chem. 68, 327-332 (2000).

18) Winning, H.; Viereck, N.; Salomonsen, T. Quantification of blockiness in pectins - A comparative study using vibrational spectroscopy and chemometrics. Carbohydr. Res. 344, 1833-1841 (2009).

19) Hori, R.; Sugiyama, J. A combined FT-IR microscopy and principal component analysis on softwood cell walls. Carbohydr. Polym. 52, 449-453(2003).

20) Sukhotu, R. Aqueous enzymatic extraction method of Maize Germ oil bodies and their physiochemical properties. China Agricultural University, Beijing, China (2014).

21) Li, T.; Peng, Y.; Li, Q. Study on extraction and structure of four kinds of peanut proteins. J. Food Sci. Technol. 33(3), 35-42 (2015).

22) Li, H.; Han, T.; Jin, P. Study on degradation characteristics of cell wall polysaccharides during post-ripening and softening of winter jujube. Journal of Chinese Institute of Food Science and Technology 14(2), 109-117 (2014).

23) He, C.W. Chemical evidence and functional study of silicon-hemicellulose complex in cell wall of rice (Oryza sativa). Huazhong Agricultural University, Wuhan, China (2015).

24) Hou, M.L. Food analysis. Chemical Industry Press, Beijing, China, vol. 5, pp. 89-90 (2004).

25) Han, Y.S. Food chemistry experiment guide. Beijing agricultural university press, Beijing, China, pp. 19-21 (1992).

26) Gao, J.F. Experimental guidance on plant physiology. Higher Education Press, Beijing, China, pp. 140150 (2006).

27) Szymanska-Chargot, M.; Zdunek, A. Use of FT-IR spectra and PCA to the bulk characterization of cell wall residues of fruits and vegetables along a fraction process. Food Biophysics 8, 29-42 (2013).

28) Fei, X.; Li, L.; Aimin, S. Composition, structures and functional properties of peanut seed protein at subunit level: A review. Food Science 37 (7), 264-269 (2016).

29) Yan, L.; Guanli, Z.; Xinguo, S. Functional and conformational properties of arachin and conarachin. Modern Food Science and Technology 29, 2095-2101 (2013).

30) Yapo, B.M.; Koffi, K.L. The polysaccharide composition of yellow passion fruit rind cell wall: Chemical and macromolecular features of extracted pectins and hemicellulosic polysaccharides. J. Sci. Food Agric. 88, 2125-2133 (2008).

31） Kačuráková, M.; Smith, A.C.; Gidley, M.J. Molecular interactions in bacterial cellulose composites studied by 1D FT-IR and dynamic 2D FT-IR spectroscopy. Carbohydr. Res. 337, 1145-1153(2002).

32) Frankova, L.; Fry, S.C. Biochemistry and physiological roles of enzymes that 'cut and paste' plant cell-wall polysaccharides. J. Exp. Bot. 64, 3519-3550 (2013).

33) Fellah, A.; Anjukandi, P.; Waterland, M.R. Determining the degree of methylesterification of pectin by ATR/ FT-IR: Methodology optimisation and comparison with theoretical calculations. Carbohydr. Polym. 78, 847853 (2009).

34) Chatjigakis, A.K. FT-IR spectroscopic determination of 
the degree of esterification of cell wall pectins from stored peaches and correlation to textural changes. Carbohydr. Polym. 37, 395-408(1998).

35) Synytsya, A.; Čopıková, J.; Matějka, P. Fourier transform Raman and infrared spectroscopy of pectins.
Carbohydr. Polym. 54, 97-106(2003).

36) Mccann, M.C.; Defernez, M.; Urbanowicz, B.R. Neural network analyses of Infrared Spectra for classifying cell wall architectures. Plant Physiol. 143, 1314-1326 (2007). 